Journal of Health Promotion and Behavior (2019), 4(1): 22-31

https://doi.org/10.26911/thejhpb.2019.04.01.03

\title{
Linear Regression Analysis on the Determinants of Hypertension Prevention Behavior
}

\author{
Nurjannah'), Setyo Sri Rahardjo²), Rossi Sanusi3) \\ 1)Masters Program in Public Health, Universitas Sebelas Maret \\ ${ }^{2)}$ Masters Program in Family Medicine, Universitas Sebelas Maret \\ 3) Study Program in Medicine, Faculty of Medicine, Universitas Gadjah Mada
}

\begin{abstract}
Background: Hypertension is a risk factor for cardiovascular events and the highest contributor to death in the world, including Indonesia. 90.08\% of health centers in DI Yogyakarta have implemented integrated non-communicable disease (NCD) control. However, the incidence of NCD including hypertension is still the highest disease seen from the top 10 diseases in Yogyakarta. This study aimed to examine the determinants of hypertension preventive behavior.

Subjects and Method: This was a cross sectional study conducted in Bantul, Yogyakarta, from February to March 2019. A total of 200 study subjects was selected by simple random sampling. The dependent variable was hypertension preventive behavior. The independent variables were self-efficacy, knowledge, family support, gender, age, and health personnel support. The data were collected by questionnaire and analyzed by a multilevel linear regression.

Results: Self-efficacy $(b=0.09 ; 95 \% \mathrm{CI}=0.03$ to $0.15 ; \mathrm{p}=0.003$, knowledge $(b=0.25 ; 95 \% \mathrm{CI}=$ 0.08 to $0.43 ; \mathrm{p}=0.004)$, family support $(\mathrm{b}=0.64 ; 95 \% \mathrm{CI}=0.34$ to $0.93 ; \mathrm{p}<0.001)$, and health personnel support $(\mathrm{b}=0.26 ; 95 \% \mathrm{CI}=0.08$ to $0.44 ; \mathrm{p}=0.008)$ increased hypertension preventive behavior. Gender $(b=0.65 ; 95 \% C I=-0.79$ to $2.10 ; p=0.372)$ and age $(b=0.01 ; 95 \% C I=-0.03$ to $0.03 ; \mathrm{p}=0.911$ ) were associated with hypertension preventive behavior but it was statistically nonsignificant.

Conclusion: Self-efficacy, knowledge, family support, and health personnel support increase hypertension preventive behavior. Gender and age were associated with hypertension preventive behavior but it was statistically non-significant.
\end{abstract}

Keywords: hypertension preventive behavior, self-efficacy, health personnel support

\section{Correspondence:}

Nurjannah. Masters Program in Public Health, Universitas Sebelas Maret. Jl. Ir. Sutami 36A, Surakarta 57126, Central Java, Indonesia. Email: nurjannah9420@gmail.com. Mobile: +6285293622882.

\section{BACKGROUND}

Hypertension is a major public health problem because its prevalence is still high and is a major risk factor for cardiovascular disease and other complications (Singh et al., 2017). World Health Organization (WHO) data shows that of the 57 million deaths that occurred in the world in 2008, 36 million or nearly two thirds were caused by non-communicable diseases (NCD). NCD also kills residents of a younger age. In countries with low and middle economic le- vels, of all fatalities that occur in people aged less than 60 years, $29 \%$ are caused by NCD, whereas in developed countries, cause $13 \%$ of deaths. The proportion of NCD deaths in people aged less than 70 years, cardiovascular disease is the biggest cause (39\%) (Ministry of Health of Republic of Indonesia, 2012).

Based on the preliminary studies in Bantul, high NCD cases were seen from 10 major diseases, namely the incidence of Essential Hypertension of 37,692 cases, Schizophrenia of 4,402 cases, Arthritis by 1,958 
cases, and non-independent Diabetes Mellitus 1,859 cases (Health Office Bantul Region, 2018).

Factors that trigger the occurrence of hypertension are not only from biological factors but there are also other factors, namely from a person's behavioral factors (Puspita et al., 2017). Murti (2018) said that in the theory of PRECEDE-PROCEED Model, factors that influence behavior, namely: predisposing factor (knowledge) and reinforcing factor (family support and support of health workers). The triad model of reciprocal determinism in social cognitive theory, behavior is influenced by personal factors namely self-efficacy and demographic variables such as age and sex influence a person's health behavior in the theory of Health Belief Model. This study aimed to examine determinants of hypertension preventive behavior.

\section{SUBJECTS AND METHOD \\ 1. Study Design \\ This was a cross sectional study carried out at integrated health post (Posbindu) in Bantul, Yogyakarta, from February to March 2019.}

\section{Population and Sample}

The population of this study was Posbindu participant members aged 17 to 70 years old. A sample of 200 study subjects was selected by simple random sampling.

\section{Study Variables}

The dependent variable was hypertension preventive behavior. The independent variables were self-efficacy, knowledge, family support, gender, age, and health personnel support.

\section{Operational Definition of Variables}

Self-efficacy was a person's belief in his ability to carry out hypertensive prevention behaviors. Knowledge was an individual's understanding of hypertension and how to prevent it. Family support was the attitude of the family to help family members face a problem. Gender was a biological characteristic possessed by Posbindu participants, namely women and men.

Age was the age of the Posbindu participants from the beginning of the birth until the time the study was conducted. Health personnel support was the attitude of health care workers in providing services to patients or Posbindu members.

Hypertension preventive behavior was defined as prevention efforts carried out by individuals so as not to cause hypertension or hypertension is not severe or cause other diseases in improving their health status.

\section{Study Instruments}

The data of hypertension preventive behavior, self-efficacy, knowledge, family support, gender, age, and health personnel support were collected by a set of questionnaire.

\section{Data Analysis}

Univariate analysis was performed to obtain frequency distribution and percentage characteristics of the research subjects. Bivariate analysis was performed to analyze the relationship between the independent variables and the dependent variable using a linear regression test with a graphical display. Multivariate analysis was performed using multiple linear regression analysis.

\section{Research Ethics}

The ethics of this study include informed consent, anonymity, confidentiality, and ethical approval. Research ethics was obtained from the Research Ethics Committee, Faculty of Medicine, Universitas Sebelas Maret, Central Java, with the number: 411 / UN27.6 / KEPK / 2019.

\section{RESULTS}

1. Characteristics of Study Subjects

Table 2 showed that the characteristics of the research subjects were mostly in the age 
Journal of Health Promotion and Behavior (2019), 4(1): 22-31

https://doi.org/10.26911/thejhpb.2019.04.01.03

range <6o years, namely amounting to 174 (87\%). The characteristics of the research subjects based on gender were mostly pos-

Table 1. Samples characteristics (continuous data)

\begin{tabular}{lccccc}
\hline \multicolumn{1}{c}{ Variable } & n & Mean & SD & Min & Max \\
\hline Self-efficacy & 200 & 66.0 & 6.8 & 35 & 85 \\
Knowledge & 200 & 9.9 & 2.4 & 2 & 13 \\
Family Support & 200 & 7.9 & 1.5 & 2 & 10 \\
Age (year) & 200 & 45.9 & 12.6 & 19 & 70 \\
Health personnel support & 200 & 9.7 & 2.4 & 3 & 12 \\
\hline
\end{tabular}

Table 2. Sample characteristics (categorical data)

\begin{tabular}{lcc}
\hline \multicolumn{1}{c}{ Characteristics } & n & \% \\
\hline Age & & \\
< 6o years & 174 & 87 \\
> 6o years & 26 & 13 \\
Gender & & \\
Male & 17 & 8.5 \\
Female & 183 & 91.5 \\
Education & & \\
Primary school & 56 & 28 \\
Junior high school & 52 & 26 \\
Senior high school & 73 & 36.5 \\
Diploma I-III & 9 & 4.5 \\
Diploma IV/ Bachelor & 10 & 5 \\
\hline
\end{tabular}

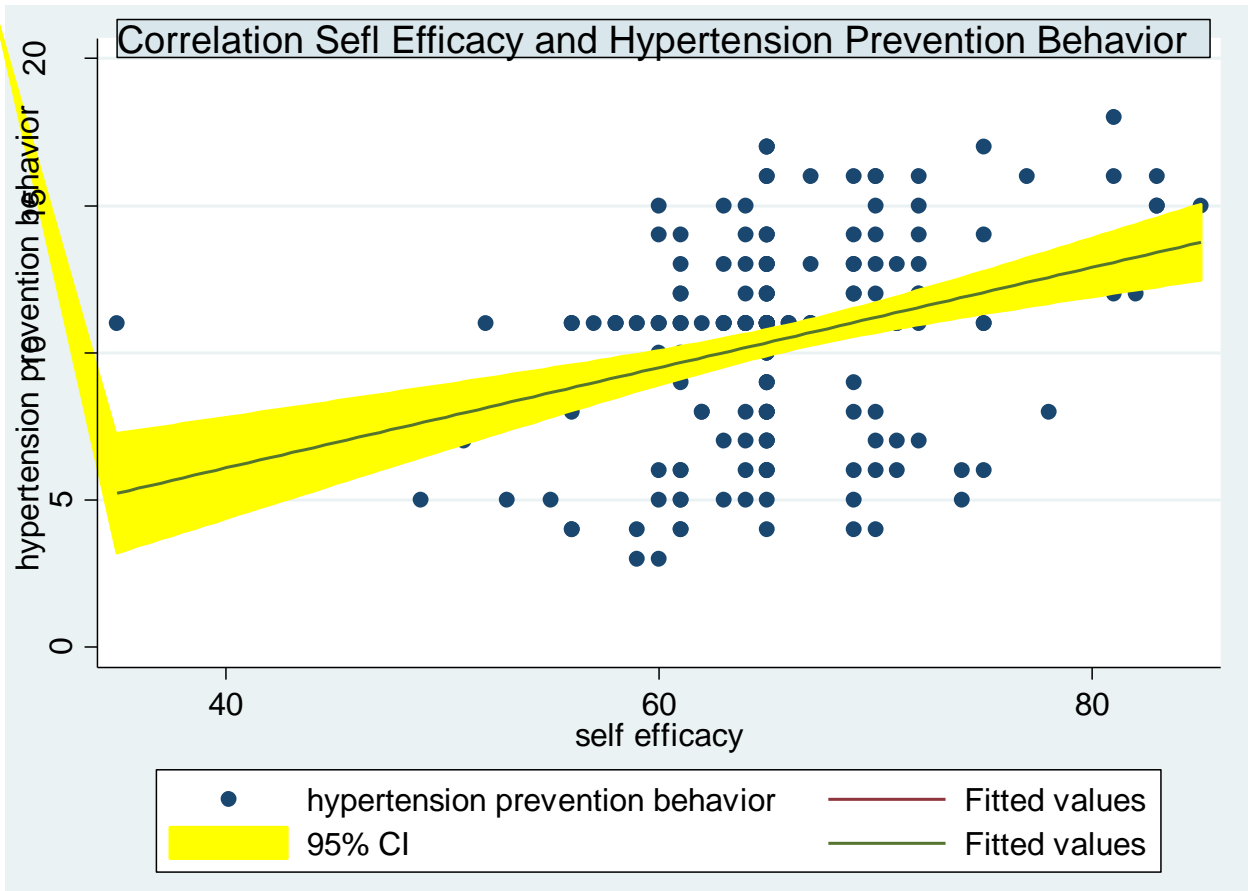

Figure 1. The regression line correlation between self-efficacy and hypertension preventive behavior 
Nurjannah et al./ Linear Regression Analysis on the Determinants of Hypertension

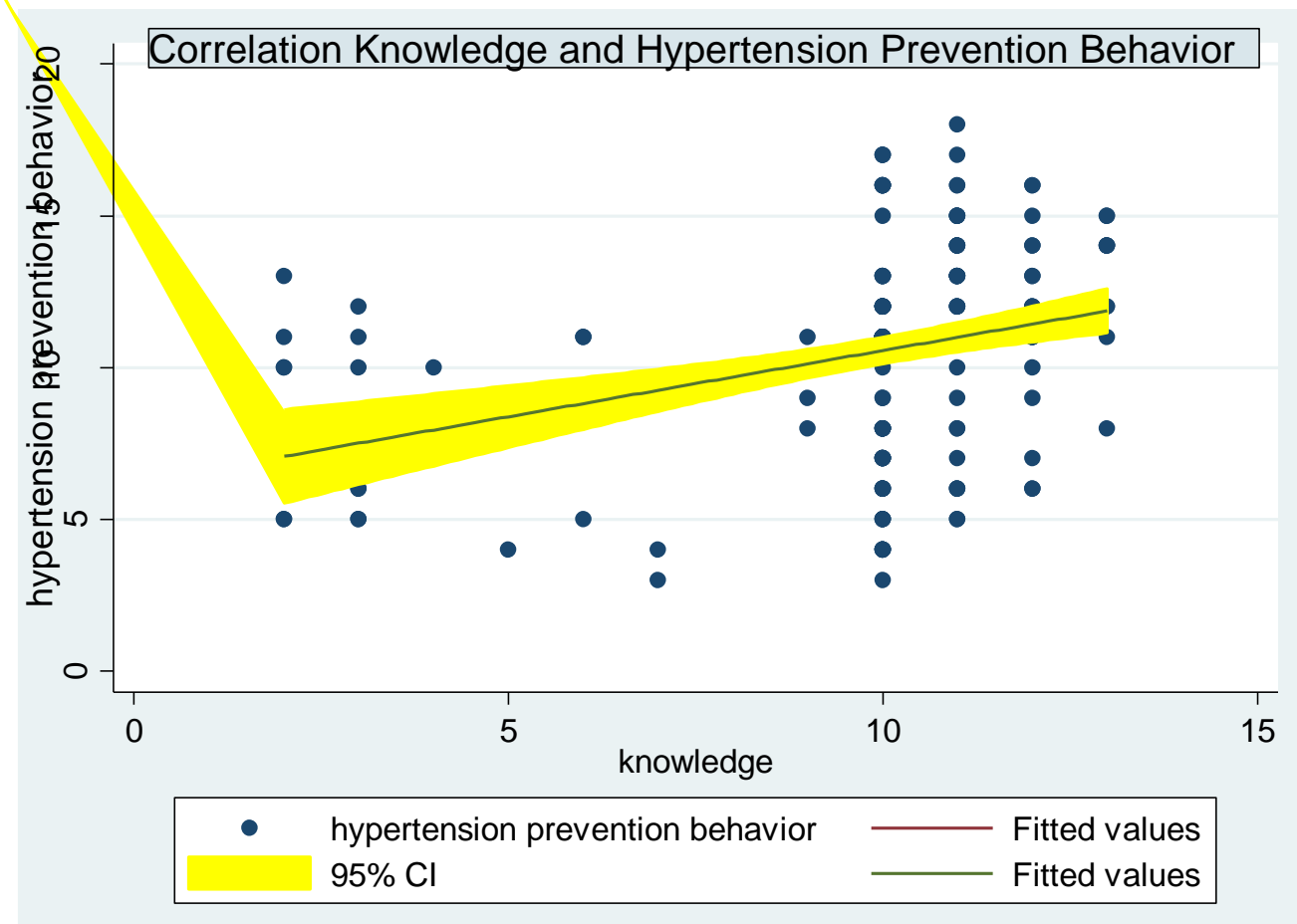

Figure 2. The regression line relationship between knowledge and hypertension preventive behavior

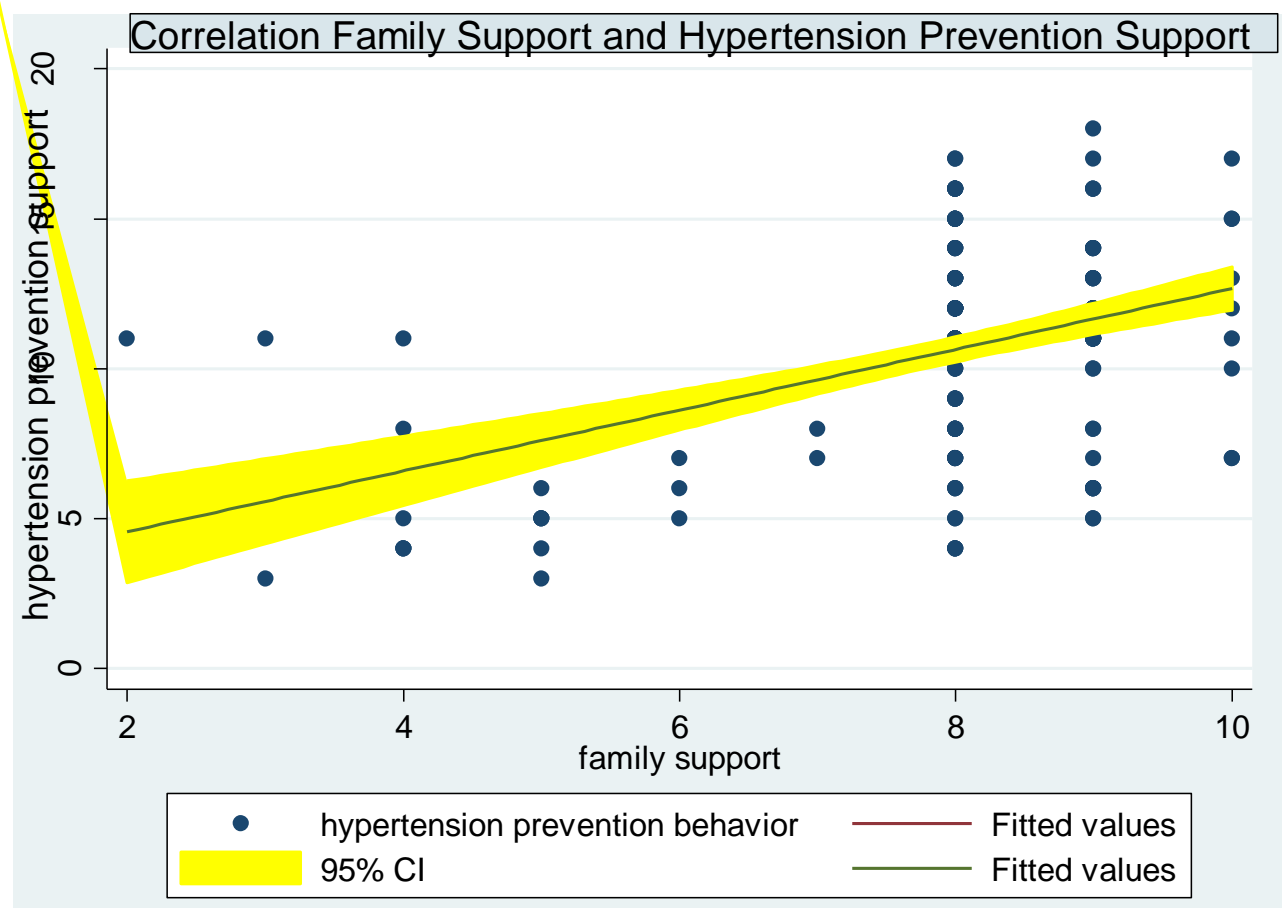

Figure 3. The regression line relationship between family support and hypertension preventive behavior 
Journal of Health Promotion and Behavior (2019), 4(1): 22-31

https://doi.org/10.26911/thejhpb.2019.04.01.03

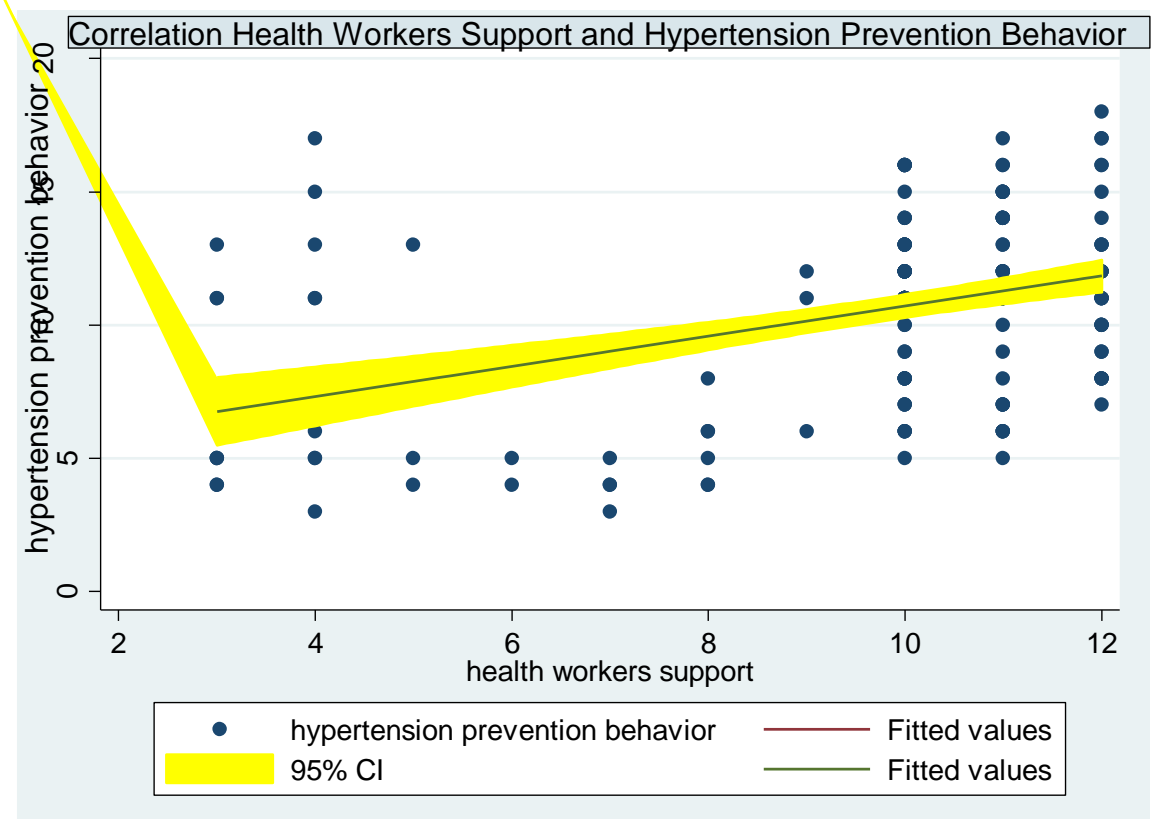

Figure 4.The regression line relationship between the health personnel support and hypertension preventive behavior

\section{Bivariate Analysis}

Figure 1 showed that there was a positive relationship between self-efficacy and hypertension prevention behavior. Figure 2 showed that there was a positive relationship between knowledge and behavior to prevent hypertension. Figure 3 showed that

Table 3. Multivariate analysis on the factors affecting hypertension preventive behavior

\begin{tabular}{lcccc}
\hline \multirow{2}{*}{ Independent Variables } & \multirow{2}{*}{ b } & \multicolumn{2}{c}{$\mathbf{9 5 \%}$ CI } & \multirow{2}{*}{ p } \\
\cline { 3 - 4 } & & Lower Limit & Upper Limit & 0.003 \\
Self-efficacy (strong) & 0.09 & 0.03 & 0.15 & 0.004 \\
Knowledge (high) & 0.25 & 0.08 & 0.43 & $<0.001$ \\
Family support (strong) & 0.64 & 0.34 & 0.93 & 0.372 \\
Male & 0.65 & -0.79 & 2.10 & 0.911 \\
Age (older) & 0.001 & -0.03 & 0.03 & 0.008 \\
Health personnel support (yes) & 0.26 & 0.08 & 0.44 & -1.84 \\
Constant & -6.74 & -11.64 & -1.84 & \\
N observation & 200 & & & \\
Adj R-squared & 0.31 & & & \\
p & $<0.001$ & & & \\
\hline
\end{tabular}

\section{Multivariate Analysis}

Based on Table 3 there is a positive relationship between self-efficacy towards hypertension prevention behavior and statistically significant. Posbindu participants who had high self-efficacy on average had a there was a positive relationship between self-efficacy and preventive behavior of hypertension. Figure 4 showed that there was a positive relationship between selfefficacy and preventive behavior of hypertension.

hypertension prevention behavior score of o.09 units higher than Posbindu participants who had low self-efficacy $(b=0.09$; $95 \% \mathrm{CI}=0.03$ to $0.15 ; \mathrm{p}=0.003$ ). Based on Table 3, there was a relationship between knowledge and hypertension preventive 
behavior and it was statistically significant. Posbindu participants who had a high knowledge have hypertension preventive behavior score of 0.25 units higher than those who had low knowledge $(b=0.25$; 95\% CI=0.08 to $0.43 ; \mathrm{p}=0.004$ ).

There was a relationship between family support and hypertension preventive behavior and it was statistically significant. Posbindu participants who had high family support have hypertensive preventive behavior score of 0.64 units higher than those who had lack of family support $(b=0.64$; 95\% CI= 0.34 to $0.93 ; \mathrm{p}<0.001$ ).

Gender was correlated with hypertension preventive behavior, but it was statistically non-significant $(\mathrm{b}=0.65 ; 95 \% \mathrm{CI}=$ 0.79 to $2.10 ; \mathrm{p}=0.372$ ). Male were 0.65 times more likely to have high hypertension preventive behavior compared to female.

Age was correlated with hypertension preventive behavior, but it was statistically non-significant $(\mathrm{b}=0.001 ; 95 \% \mathrm{CI}=-0.03$ to $0.03 ; \mathrm{p}=0.911)$. Age $>46$ years old was 0.001 times more likely to have high hypertension preventive behavior compared to age $<46$ years old.

There was a positive association between health personnel support and hypertension preventive behavior, and it was statistically significant $(b=0.26 ; 95 \% \mathrm{CI}=0.08$ to $0.44 ; \mathrm{p}=0.008$ ).

\section{DISCUSSION \\ 1. The Effect of Self-Efficacy on $\mathrm{Hy}$ - pertension Preventive Behavior}

The results of this study showed that there was a significant effect of self-efficacy on hypertensive prevention behavior. Posbindu participants who have high efficacy can increase the likelihood of having high hypertension prevention behaviors. This study was in line with the research of Han et al. (2014), which stated that self-efficacy was related to hypertension self-care and has a strong relationship $(\mathrm{r}=0.54, \mathrm{p}$ $<0.001)$. Self-efficacy in self-care was a major factor in facilitating lifestyle changes. Therefore, increasing someone's self-efficacy was a promising way to improve someone's health prevention behavior as well.

This study was in line with Setyaningsih et al., (2016), which stated that there was a direct relationship between self-efficacy and hypertension prevention behavior ( $b=0.31 ; p<0.001)$. With confidence, someone would believe that doing preventive behavior would avoid the occurrence of hypertension (Puspita et al., 2017). The study of Skinneret et al., (2000) in Setiyaningsih et al., (2016), identified two key dimensions of effective therapy to improve the success of hypertension treatment, namely the belief that therapy can control hypertension and the belief that therapy can prevent complications from the illness.

Self-efficacy or belief in their ability to behave was an important element in increasing self-management of chronic diseases such as prevention of hypertension (Findlow et al., 2012). Processes that were activated efficacy played a key role in regulating self-motivation and helping patients to achieve treatment goals for their illness in the following four ways: mastery experience, verbal persuasion, emotional arousal, and representative experience. This was the most effective way to increase self-efficacy, mastery experience can be improved through advice from health staff in preventing hypertension (Lee and Park, 2017).

Maintaining adherence to a hypertensive diet as a manifestation of hypertension prevention behavior was a very strong commitment. Dietary care included maintaining the desires of the individual himself and resisting the temptations of an unhealthy lifestyle to avoid hypertension (Kamran et al., 2015). 
Journal of Health Promotion and Behavior (2019), 4(1): 22-31

https://doi.org/10.26911/thejhpb.2019.04.01.03

\section{The Effect of Knowledge on Hyper- tension Preventive Behavior}

This study showed that there was a significant effect on knowledge of hypertension prevention behavior. Posbindu participants who have high knowledge can increase the likelihood of having high hypertension prevention behaviors.

Knowledge of hypertension was very important to help someone in making a decision based on the information they got (Asmah and Orkoh, 2017). Sufficient knowledge about hypertension was related to the level of adherence and control of blood pressure better. This showed that it wass necessary to increase someone's knowledge through group education, for example counseling in the prevention of hypertension (Almas et al., 2012).

Study of Gamage and Jayawardana (2018) stated that the knowledge and practices of lifestyle of teenagers with regard to NCD and their primary prevention were found to be unsatisfactory. This highlighted the importance of building a system for monitoring NCD risk factors, and implementing awareness-raising programs among these groups. The strategy that must be carried out includes the establishment of schools that promote health through school health clubs, with healthy canteen policies, which must be adhered to. The fact that children were considered as agents of the best change to spread knowledge and practice to families and communities must be explored to the full, because this proved to be beneficial for adolescents and adults equally.

Knowledge affected a person in behaving and behaving obediently or not to diet hypertension in an effort to prevent hypertension. Having access to information by utilizing mass media and through health care providers was very possible to gain knowledge and promote changes in attitude about the complaints they suffer (Chotisiri et al., 2016).

\section{The Effect of Family Support on} Hypertension Preventive Behavior

This study showed that there was a significant influence of family support on the behavior of preventing hypertension. Posbindu participants who have high family support can increase the likelihood of having high hypertension prevention behaviors. Jannah et al., (2018) stated that family support and preventive behavior of a person's health were significantly related.

Increasing family support has very important health implications for family members. It also affected behavior change. If someone in the family behaves well, it was more likely that other family members would follow. The function of the family was also a place of refuge and as the first place for its members to communicate about complaints they suffer (Huidobro and Mendenhall, 2015).

Hospital administrators must implement policies that include interventions that must include family support services, which were considered as a better way to build natural support from family members and friends and health care providers (Lee and Park, 2017).

\section{The Effect of Gender on Hyper- tension Preventive Behavior}

There was no relationship between gender and hypertension preventive behavior. In this study, Posbindu participants who were male had higher hypertension prevention behavior than women. In this study, the majority of the respondents studied were women, because most of the participants in the Posbindu activity were women.

Gender was known to have no effect on physical activity levels in the prevention of hypertension. This was because it can occur because the respondents of male or female have almost the same activities (Ris- 
kawati et al., 2018). In searching for health services and treatment, women did not always have the time to come to health services because many women also work/ have a busy life (Rasajati et al., 2015).

The difficulty to identify the influence of gender on the behavior of preventing hypertension was related to sampling problems which were often difficult to get balanced samples in terms of numbers. In this study, this happened, because the number of women who participated in the Posbindu activity in order to prevent hypertension was greater than men.

\section{The Effect of Age on Hypertension Preventive Behavior}

There was no relationship between age and hypertension prevention behavior. Based on this study, the relationship of age to hypertension prevention behavior showed no significant relationship. Posbindu participants aged $>46$ years old had a high preventive behavior of 0.001 times higher than Posbindu participants aged <46 years old. Differences in the prevention of hypertension were very small or almost the same between Posbindu participants with age $>46$ years old and $<46$ years old $(b=0.001$; $\mathrm{p}=0.911)$.

Miyusliani and Yunita (2011), stated that the older the person, the person's mindset was more childish, they want to be followed by all their desires so that prevention of hypertension or a recommended healthy diet did not go well.

Age factors were known not to have a significant effect on the level of physical activity because the behavior depends on the habits that have been implemented before. Even so, if physical activity was routinely carried out from childhood, it can increase the likelihood of a person having sufficient physical activity as an adult (Riskawati et al., 2018). Novian (2013) study stated that an elderly person might not be able to con- tinuously prevent hypertension properly, and also young person. This showed that age did not significantly affect the behavior of preventing hypertension.

Increasing age was indeed a risk factor that caused hypertension. This was called the silent killer for the community because it was sometimes considered trivial so that it was only felt if it was severe. However, this did not always affect how they behave in preventing hypertension. This was sometimes influenced by a person's mindset and other factors that cause them not to behave properly. Sometimes they have applied good health behavior patterns, but did not do it properly so it can lead to hypertension.

\section{The Effect of Health Personnel Support on Hypertension Preven- tive Behavior}

This study showed that there was a significant influence of family support on the preventive behavior of hypertension. Posbindu participants who have high family support can increase the likelihood of having high hypertension prevention behaviors.

This study was in line with Maharani and Syafrandi (2017), which stated that there was a relationship between the role of health personnel and blood pressure control behavior $(\mathrm{OR}=2.80 ; 95 \% \mathrm{CI}=1.40$ to 5.56; $\mathrm{p}=0.005$ ).

Health workers were involved in providing support in a person's self-management (Ursua et al., 2018). The role of health workers as the basic information provider and understanding of how to do a healthy diet and lifestyle in hypertension prevention, and the right time to treat and control hypertension (Allen et al., 2016) The support of health personnel was very important where officers were managers, because officers were the ones who interact most often, so that understanding of physical and psychological conditions got better. So that 
Journal of Health Promotion and Behavior (2019), 4(1): 22-31

https://doi.org/10.26911/thejhpb.2019.04.01.03

it can affect trust and acceptance of the presence of health personnel can be grown in a person properly (Novian, 2013).

\section{AUTHOR CONTRIBUTION}

Nurjannah collected the data, wrote the manuscript, and draw the figures and tables. Setyo Sri Rahardjo suggested the methodology. Rossi Sanusi contributed to data analysis and interpreted the results of data analysis.

\section{FUNDING AND SPONSORSHIP}

This study used the authors' independent costs.

\section{ACKNOWLEDGEMENT}

The author would like to say thank you to the Head of Banguntapan I, Bantul I, Kretek, Sewon I, Dlingo I, and Piyungan Health Centers, Yogyakarta, for assistance in data collection.

\section{CONFLICT OF INTEREST}

There is no conflict of interest in this study.

\section{REFERENCE}

Almas A, Godil SS, Lalani S, Samani ZA, Khan AH (2012). Good knowledge about hypertension is linked to better control of hypertension; A multicentre cross sectional study in Karachi, Pakistan. Biomed Central Research. 5 (579): 1-8. doi: 10.1186/1756-0500-5579

Allen CG, Brownstein JN, Satsangi A, Escoffery C (2016). Community health workers as allies in hypertension selfmanagement and medication adherence in the United States, 2014. Preventing Chronic Disease Public Health Research, Practice and Policy. 13 (E179): 1-10. doi: 10.5888/pcd13.160236

Asmah EE, Orkoh E (2017). Self-care know- ledge of hypertension prevention and control among women in contemporary Ghana. American Journal of Health Education. 48(6): 374-381. doi: 10.1080/19325037.2017.1358120

Chotisiri L, Yamarat K, Taneepanichskul S (2016). Exploring knowledge, attitudes, and practices toward older adults with hypertension in primary care. Journal of Multidisciplinary Healthcare. 9: 559-564. doi: 10.2147/JMDH.S112368

Health Office Bantul Region (2018). Profil Kesehatan Kabupaten Bantul Tahun 2018 (Data 2017). Yogyakarta

Findlow JW, Seymour RB, Huber LRB (2012). The association between selfefficacy and hypertension self-care activities among African American Adults. Journal Community Health. 37(1): 15-24. doi: 10.1007/s10900011-9410-6

Gamage AU, Jayawardana PL (2018). Knowledge of non-communicable diseases and practices related to healthy lifestyles among adolescents, in state schools of a selected educational division in Sri Lanka. BMC Public Health. 18(64): 1-9. doi: 10.1186/s12889-0174622-z.

Han HR, Lee H, Mensah YC, Kim M (2014). Development and validation of the hypertension self-care profile: A practical tool to measure hypertension self care. Journal of Cardiovascular Nursing. 29(3): 11-20. doi: 10.1097/JCN.obo13e3182a3fd 46

Huidobro DG, Mendenhal T (2015). Family oriented care: Opportunities for health promotion and disease prevention. Journal of Family Medicine and Disease Prevention. 1(2): 1-6. Doi: 10.23937/2469-5793/1510009

Jannah N, Tamtomo D, Soemanto RB (2018). Factors associated with heal- 
thy preventive behavior among the elderly in Lamongan, East Java. Journal of Health Promotion and Behavior. 3(4): 223-229. doi: 10.26911/thejhpb.2018.03.04.01.

Kamran A, Azadbakht L, Sharifirad G, Mahaki $\mathrm{B}$, Mohebi S (2015). The relationship between blood pressure and the structures of Pender's health promotion model in rural hypertension patients. Journal of Education and Health Promotion. 4(29): 1-8. doi: 10.4103/2277-9531.154124.

Ministry of Health (2012). Buletin Jendela Data dan Informasi Kesehatan PTM. Jakarta. http://www.depkes.go.id/resources/download/pusdatin/buletin/ buletin-ptm.pdf.

Lee E, Park E (2017). Self-care behaviour and related factors in older patients with uncontrolled hypertension. Journal Contemporary Nurse. 1-15. doi: 10.1080/10376178.2017.1368401.

Maharani R, Syafrandi DP (2017). Faktor yang berhubungan dengan perilaku pengendalian tekanan darah pada penderita hipertensi di Puskesmas Harapan Raya Kota Pekan Baru. Jurnal Kesehatan Komunitas. 3(5): 165171. doi: 10.25311/keskom.Vol3.Iss5.122

Miyusliani S, Yunita (2011). Faktor resiko yang berpengaruh terhadap kepatuhan diet hipertensi. Jurnal Kesehatan Komunitas. 1(3): 163-169 doi: 10.25311/jkk.Vol1.Iss3.21.

Murti B (2018). Teori promosi dan perilaku kesehatan. Colomadu: Bintang Fajar Offset

Novian A (2013). Kepatuhan diet pasien hipertensi. Jurnal Kesehatan Masyarakat. 9(1): 100-105. doi: 10.15294/kemas.v9i1.2836
Puspita RC, Tamtomo D, Indarto D (2017). Health belief model for the analysis of factors affecting hypertension preventive behavior among adolescents in Surakarta. Journal of Health Promotion and Behavior. 2(2): 183-196. Doi: 10.26911/thejhpb.2017.02.02.08 Rasajati QP, Raharjo BB, Ningrum DNA (2015). Faktor-faktor yang berhubungan dengan kepatuhan pengobatan pada penderita hipertensi di wilayah kerja Puskesmas Kedung Mundu Kota Semarang. Unnes Journal of Public Health. 4(3): 16-23 ISSN: 2252-6528

Setyaningsih R, Tamtomo D, Suryani N (2016). Health Belief Model: Determinants of hypertension prevention behavior adults at community health center, Sukoharjo, Central Java. Journal of Health Promotion and Behavior. 1(3): 161-171. doi: 10.26911/thejhpb.2016.01.03.03

Singh S, Shankar R, Singh GP (2017). Prevalence and Associated Risk Factors of Hypertension: A Cross-Sectional Study in Urban Varanasi. International Journal of Hypertension. 2017 (2017): 1-10. doi: 10.1155/2017/5491838

Ursua RA, Aguilar DE, Wyatt LC, Shevrin CT, Gamboa L, Valdellon P, Perella EG et al (2018). A community health worker intervention to improve blood pressure among Filipino Americans with Hypertension: A Randomized Controlled Trial. Preventive Medicine Reports. 11(2018): 42-48. doi: 10.1016/j.pmedr.2018.05.002. 